\title{
Defining Islam for the Egyptian State
}

\author{
By Jakob Skovgaard-Petersen. Leiden: Brill, 1997, 423 pp.
}

Defining Islam for the Egyptian state is as interesting historical study of an important religious institution in Egypt: The State Fatwa Office (Där al Iftā'). It traces this institution's development from its inception in 1895 to the last quarter of the twentieth century, focusing on the role of official muftis and their "sometimes ungratefu! task" of defining Isiam for both the state and an increasingly conscious Muslim public (p. 1).

Uncomfortably situated between a state bureaucracy and an emerging Muslim public concemed with the transmission of Islamic values, occupiers of the seat of $i f t \bar{a}^{\prime}$ were burdened with the task of asserting the compatibility of Islam with modern demands. Thus, their fatwas were different from those of their predecessors in that they were vested with new institutional authority and directed toward a Muslim public that did not exist before the end of the nineteenth century. Therefore, this study goes beyond the office's role as an official or state institution to analyze further its relation to Egypt's Islamic political discourse. As this office occupies a well-defined position in Egyptian society, serves as the mouthpiece of an official Islam that has opted for accommodation between state and religion, and produces fatwas within the framework of existing state law, studying Dār al Iftă’ offers significant advantages. By analyzing representative samples of its fatwas in their social and political contexts, this study demonstrates how such fatwas can be used as a source for studying modern Islamic social and intellectual history. In this sense, the history of $\bar{D} \bar{r}$ al Ifta' ' provides a rare glimpse into major themes of twentiethcentury Islamic thinking. The main source for following its historical development is its work - the fatwas it has issued (book cover \& p. I). 
Skovgaard-Petersen's thesis is that although state muftis represented the interests of the state, they have seen themselves less as governmental functionaries than as defenders of the faith against the onslaught of secularization. Accordingly, they have striven to Islamize society and reconquer territory lost in the economic, political, social, and moral spheres with the goal of reincorporating them into the Islamic field of meaning. In their endeavor to serve the state, while upholding their authority and combating materialistic currents, state muftis have actually contributed to a reformulation of Islam as simple, rational, just, and easily applicable, which presents "a vision of Islam that has been highly influential in the 20th century" (p. 29).

According to Skovgaard-Petersen, fatwas not only contributed to Islamizing people's conduct, but actually brought all sorts of human action into the sphere of figh (jurisprudence). "The fatwa and mufti then, are situated at the interface between worldly dealings and theorizing about them." While they had no coercive power to impose their fatwas, the latter, in their totality, constituted part of "Muslim society's understanding and representation of itself" over generations (p. 2). In this sense, the study of fatwas is justified as an attempt to demonstrate how they can be used as sources for legal, social, intellectual, and mental history.

Apart from other analyses of fatwas, which range from individually significant and important ones to the whole corpus of a particular mufti, Skovgaard-Petersen maintains that one method of studying fatwas has not been used: a structural analysis of a major fatwa collection. A study of the intertextuality of fatwas, focusing on the norms and categories employed, would shed light on the worldview of a particular period and could yield results different from those obtained by other means. Skovgaard-Petersen expresses particular doubts and reservations regarding methods and cases that disregard the historical context of fatwas and thus reduce their value for the study of Islamic dogma and ideology (p. 13).

The study is divided into two overlapping parts. The first part (chapters Two and Four to Nine) trace the historical development of Dār al Iftā'. The second part analyzes four case studies/fatwas. However, whereas case studies/fatwas II, III, and IV are included in later chapters (chapters Five, Six, and Seven), Case Study I, apparently to maintain a chronological order, is incorporated into Chapter Three. The four accompanying appendices present a list of the Dār al Iftā' muftis, the Dār al Iftā' records, a compilation of fatwas on insurance, and finally a glossary of Arabic words used in the text. The study uses two main sources, which it terms external and internal. The former includes biographical dictionaries of 'ulamā', writings by the 'ulamā' themselves or the British Residency (later embassy), books written by some of the muftis, fatwas published in newspapers and magazines and, finally, the archives of the British Residency and Foreign Office. The internal sources are essentially the records of Dār al Iftā' (pp. 30-32).

Chapter One examines the origin of the concept of ift $\bar{a}^{\prime}$, reviews the literature, and discusses some methodological issues pertaining to how the study was conducted. Chapter Two is a historical account of political, educational, legal, and religious developments in nineteenth-century Egypt. It examines the organizational structure of al Azhar; the impact of printing on the dissemination of religious knowledge and fatwas through newspapers, magazines, and other publications; and the emerging influence of the Șalafi movement promulgated by such prominent intellectual Muslims as Muḥammad 'Abduh and Rashīd Riḍā. Chapter Four examines the establishment of Dār al Iftā' on 21 November 1895, the role of the mufti, and the gradual institutionalization of the Hanafi school of thought (Egypt was an Ottoman territory) in a predominantly Shāfi'i country.

The second part of the chapter examines and analyzes the lives and some of the fatwas of prominent muftis who occupied that position even before the establishment of Dār 
al Iftā'. The list includes Muhammad al 'Abbāsĩ al Mahdī (1848-97); Ḥassūnah al Nawawī (1895-99), the first mufti of Där al Iftä' proper; and Muhammad 'Abduh (1899-1905), the leading representative of the Șalafi movement and the major figure of Islamic reformism. The latter's famous fatwa, known as the "Transvaal fatwa," in response to a question by a Muslim from that part of the world, is discussed in some detail. To the three questions asked as to whether Muslims were permitted to wear a hat, eat meat slaughtered by Christians, and whether Shāfi'ī Muslims could pray behind Hanafĩ Muslim given some technical differences, 'Abduh's response, based on his own ijtihäd (analytical deduction), was in the affirmative. Finally, the list includes the rather inactive and less controversial Bakrī al Șadfi (1905-14) and Muhammad Bakhit (1914-20), a prolific writer and politically active mufti who opposed any attempt to abolish the office and worked diligently to reform the religous law courts (al Mahäkim al Shar'īyah).

Chapters five and six deal with other challenges that faced the state mufti. In the former chapter, which mainly covers the period between 1928-54, such challenges are seen to arise from the emergence of other fatwa bodies, such as the Corps of High 'Ulamā' at al Azhar University, which emerged out of the Azhar Organization law of 1911. The Corps consisted of 30 seats divided among representatives of different Sunni schools of thought: 11 Ḥanafìs, 9 Shāfi'ìs, 9 Mālikīs, and 1 Hanbalī. Other bodies included the Azhar Fatwa Council (Lajnat al Fatāwä bi al Azhar), which was inaugurated in 1935 by the Șalafi shaykh of al Azhar Mușțafă al Marāghī and contained twelve members from different madhähib. The growth of lay influence, in the form of the Muslim Brotherhood (neoSalafi) and its associated internationalism, also was a significant challenge not only to the state mufti's authority but to any body perceived as subject to state influence. Its rise had to do with Egypt's political climate and the spread of literacy and secular schooling. Founded by Hassan al Bannā' in 1928, it was the most conspicuous reaction to the suppression of religious teaching in the public school system and to the British presence. Nevertheless, the two most prominent muftis during this period were 'Abduh's disciple 'Abd al Majīd Salīm (1928-45), and the more conservative and anti-Șalafĩ Hasanayn Muhammad Hasanayan Makhlūf (1946-50, 1952-54), both of whom maintained the authority and influence of the Dār al Iftā'.

The Egyptian revolution of 1952 and the rise of Gamal Abdel Nasser to power brought about significant changes in the fortunes of the 'ulamā'. The previous power balance between the Palace, the Parliament, and the British gave way to pervasive state control and a growing bureaucracy. Chapter Six examines the period between 1954-78, during which muftis were eclipsed by the state and the victory of the moderate Șalafi faction of the 'ulamā'. This was particularly true after the revolution's crackdown on the Muslim Brotherhood in 1954, which undermined the structure of the neo-Salafi movement. The nationalization of the $a w q \bar{a} f$ (religious endowments) and the abolishment of al Mahākim al Shar'īyah in 1956 further had a profound impact on Egypt's 'ulamā' and religious institutions. While nationalization undermined these institutions' economic independence, the latter opened the door for graduates from secular universities for a career in the personal status legal sector (previously the preserve of al Azhar candidates). No wonder some Muslims claimed that such measures were directed at Islam.

The new regime's purpose, however, was to bridge the gap between Islamic and secular legal and educational systems, a development that had contributed to social fragmentation. These measures were followed by the Law Number 103 of 1961 for the reorganization of al Azhar. During this period, the mufti had limited, if any, political influence or public role. Islam was used to mobilize the people to achieve goals set by the state and as an ideological weapon against the monarchies of the Arabian peninsula, while al Azhar was incorporated as an instrument of state legitimization. 
The tide seemed to turn after Nasser's death and his successor's (Anwar al-Sadat) change of course. Chapter Seven deals with the Islamization agenda. In seeking to undermine the influence and power of internal leftist forces, Sadat released members of the Muslim Brotherhood from jail and attempted to mobilize Islamic groups. He also promulgated a new constitution in 1971 , which stipulated that Islam was the state religion and that the Shariah was the principal source of legislation. This, in many ways unwittingly, provided an institutional framework for the Islamization of society, which sometimes went beyond the regime's expectations: it gave the Muslim Brotherhood a chance to join the Parliament and engage in the political process, and assisted the rise of radical and militant Islamist groups that eventually turned against the state.

The period between 1970-1990s thus witnessed both the Islamization of Egyptian society and the growing impact of political Islam. This trend was buttressed by the oil boom and the growing influence of Saudi Arabia, the social indifference of the newly enriched infitäh bourgeoisie, the state's weakened role in many social sectors (mainly due to its growing debt and privatization attempts), and other reasons related to the defeat in the 1967 war. The Islamists' turn against the state engendered further conflict with the official 'ulamā' and the state mufti. Being part of the state bureaucracy, the latter could not share the Islamists' opinions of the regime's illegitimacy due to its un-Islamic character. This brought the religious institutions squarely into the government's camp, for their own legitimacy also was being questioned commensurately.

This confrontation between Islamists and official 'ulamā' assumed new dimensions with the appointment of Jādd al Ḥaqq 'Alī Jãdd al Haqq (1978-82). Jādd al Haqq actively sought to reassert the authority of Dār al Iftā' as a competent and efficient institution (Chapter Eight). He maintained that only well-trained and qualified 'ulamā' could practice ijtihād, thus disqualifying laymen, and actually directed polemics against them, much to the satisfaction of the regime. However, what discredited Jādd al Haqq most in the eyes of many Muslims was his sanctioning of the new personal status law, known as "Law of Jihan" (Sadat's wife), and his support for the Camp David Peace Accords. He came to be perceived as nothing more than a government puppet. The co-optation of the 'ulamā' by the state appeared to be complete. With Jādd al Haqq' s appointment, and with his successors, the mufti "for the first time for almost a century ... became an important tool of State policy" (p. 250).

Followed by two inconspicuous muftis, 'Abd al Lațîf Hamzah (1982-85) and Muhammad Mujāhid (1985-86), the muftiship finally devolved to Muhammad Sayyid 'Ațīyah Tanțāwī (1986-97), the last mufti dealt with in this study (the current mufti is Muhammad Farīd Wāșil, 1997-). Chapter Nine examines his career and some of his fatwas and activities. From the very beginning he was mired in controversy and disputes. Many saw him as the most compliant of all the official 'ulamā', and others challenged his knowledge and ethics, especially after his 7 September 1989 fatwa sanctioning saving certificates. This particular fatwa led to the accusation that he had legalized usury (ribāa) and had a tendency to permit what he had earlier prohibited or vice versa (p. 282). Only 6 months earlier he had issued an opposing fatwa on this same question (Chapter Ten, Case Study II). This, together with his rather ambiguous fatwa (Chapter Eleven, Case Study III) on the legality of a sex change operation, subjected him to continuous criticism.

The last chapter (Case Study IV) deals with risk, the insurance industry's history in Egypt, and Egyptian fatwas on this matter over the last century. While earlier muftis prohibited insurance on the ground that it was a new type of contract unknown to figh, later muftis approved it (with the exception of multinational commercial insurance). Finally, Case Study I, in Chapter Three, examines a number of fatwas issued during the second half of the nineteenth century and early twentieth century that sought to deal with the tele- 
graph, a relatively new invention at the time, and the permissibility of using it to report lunar observations. Its main source was the Syrian Șalafī Jamãl al Dīn al Qãsimī (1911). The fatwas on the telegraph were chosen by Skovgaard-Petersen because they discussed major themes in the Șalafi vision of ift $\bar{a}$, do the fatwas concerned with the spreading of printed materials, printing, publicity, European inventions, rationality, and change. This was considered a suitable conclusion to the second chapter, which dealt with the historical background of Där al Iftā' (p. 381).

Skovgaard-Petersen's interesting study raises important questions concerning the level and degree of significance of such religious institutions in Egypt's social and political life and the extent to which they embody credible authority. Have they been effectively committed to the preservation of faith in society, linking it to the practical dimensions of social life, and if need be, have they successfully confronted or challenged the state when its policies contradicted Islamic injunctions? More crucial is whether the 'ulamā' can continue to serve a state while simultaneously upholding their credibility and authority. From a sequence of comments made throughout the book by Islamic figures, one is prone to arrive at a negative conclusion. For example, al Marāghĩ blamed the 'ulamā', whom he accuses of passivity and ignorance (p. 148), for the wretched moral condition of Egyptian society. Hassan al Bannā' perceived al Azhar as simply graduating "religious literates" rather than spiritual guides, and thus saw it as an institution that was favored by imperialists. Essentially, they were nothing more than state functionaries ('ulamā' muwažzafin) (p. 157). 'Abd al Salām Faraj, author of al Farĩdah al-Ghā'ibah and a Muslim activist executed after Sadat's assassination in 1981, argued that the 'ulamā' did nothing to resist Napoleon's invasion of Egypt (1798-1801) (p. 219). In the early 1980s, Yūsuf al Qaraḍãwi strongly criticized al Azhar and its organs in the same vein (p. 188). One senses an agreement, over time and by different people from different walks of life as well as members of these same institutions, that a religious and institutional crisis does exist, one that existed long before the so-called (and negatively perceived) nationalization of religious institutions in 1961. Skovgaard-Petersen does not deal in any depth with the underlying reasons behind such a sorry state, but does recognize in his conclusion the resulting "anarchic situation of ifta"' (p. 379).

The fact that a sense of crisis existed even when religious institutions enjoyed a good measure of economic independence and maneuvering space begs an important question: Is the asserted passivity and ignorance of the 'ulamā' an organizational-institutional outcome, a madhabi one, or both? In other words, where does the problem lie? Is there a madhabi crisis (not necessarily a religious one, although frequently the two are confused) or a paradigmatic one (in Thomas Kuhn's parlance) in the Sunni world that has translated into institutional ossification or vice versa? Which is the cause, which is the effect? Or is it symbiotic? These are complex issues that Sunnis must address, for sound answers depend strongly on asking the right and difficult questions. Skovgaard-Petersen's work, while not actually raising these inquiries, logically implies and anticipates them, especially when fatwas often seem to be nothing more than reflections of economic and political interests and expediencies (p. 312-13) or simply contexts. Irrespective of who the mufti is, it is highly disconcerting to the average Muslim to see a religious institution previously opposed to peace with Israel on religious grounds sanctioning it at a later date. One can relate a melancholic historical experience, but this suffices to ask the challenging question as to whether religion matters any more in such supposed bastions of faith and orthodoxy. It has been suggested frequently that state policies of co-optation, nationalization, and control of these institutions have led to this sorry state of affairs. However, this presumes that the same state of affairs is a recent phenomenon rather than an historical one, a claim that would very likely stand on shaky ground. 
Finally, I would like to highlight a point that Skovgaard-Petersen seems to overlook: the important differences between functional or procedural equivalence and substantive distinctions. He raises the valid issue of whether labeling a hospital or a bank, for instance, as Islamic makes it truly Islamic. The answer is certainly "no," but he seems to ignore the substantive role of premises, motives, and intentions as well as some procedural differences that are intrinsic to the core of the faith. However, his point remains valid and contentious, for superficiality could easily be mistaken for substance. Skovgaard-Petersen further seems to be willing to superimpose "Christian" secular historical experiences on Islam, arguing that in trying to prove the latter fully compatible with modern society, Muslims may simply end up endorsing secular modernity and little more. Such a proposition ignores the structural differences between the two faiths and the fact that while Islam has a religious law, Christianity by and large lacks one (pp. 22223). This constraint recasts the proposition into an empirical, rather than an epistemological, framework. Therefore, the link between this structural legal component and the nature and outcome of experiences must be tested before making sweeping and generalized statements.

Skovgaard-Petersen's study, nevertheless, is a laudable chronological effort that contributes to both the accessibility and a better understanding of Islamic law as it develops within its own context. Moreover, it is of particular relevance to those students and scholars studying and analyzing the social and intellectual history of the modern Arab world.

Amr G. E. Sabet Department of Political Science University of Tampere Tampere, Finland 